\title{
Implementasi Pembelajaran Pendidikan Agama Islam dalam Menanamkan Nilai-Nilai Religiusitas
}

\author{
Desi Purnama Sari ${ }^{1}$, Murniyetti ${ }^{2}$ \\ desipurnama512@gmail.com ${ }^{1}$, murniyetti@fis.unp.ac.id ${ }^{2}$ \\ Universitas Negeri Padang1,2
}

\begin{tabular}{|c|c|}
\hline ARTICLE INFO & \multirow{12}{*}{$\begin{array}{l}\text { ABSTRAK } \\
\text { Penelitian ini di latarbelakangi oleh kemajuan ilmu } \\
\text { pengetahuan dan teknologi yang telah membuat peserta } \\
\text { didik cenderung mencoba atau meniru apa yang dilihatnya. } \\
\text { Implementasi pembelajaran Pendidikan Agama Islam (PAI) } \\
\text { di sekolah diharapkan dapat menanamkan nilai-nilai } \\
\text { religiusitas agar nilai-nilai yang ada pada diri peserta didik } \\
\text { tidak hilang namun semakin meningkat seiring } \\
\text { perkembangan zaman. Penelitian ini bertujuan untuk } \\
\text { mengetahui: (1) Bagaimana implementasi pembelajaran } \\
\text { PAI dalam menanamkan nilai-nilai religiusitas kepada } \\
\text { peserta didik, (2) Apa faktor pendukung dan penghambat } \\
\text { dalam proses implementasi, (3) Bagaimana upaya guru } \\
\text { dalam mengatasi faktor penghambat. Jenis penelitian yang } \\
\text { penulis gunakan adalah penelitian lapangan. Sedangkan } \\
\text { metode penelitan yang penulis gunakan adalah metode } \\
\text { kualitiatif dengan pendekatan deskriptif. Hasil peneltian ini } \\
\text { menjelaskan bahwa nilai-nilai religiusitas yang ditanamkan } \\
\text { di SMA Negeri } 3 \text { Pariaman adalah nilai ibadah, nilai } \\
\text { kedisiplinan, dan nilai akhlak. Implementasi pembelajaran } \\
\text { PAI dalam menanamkan nilai-nilai religiusitas di SMA } \\
\text { Negeri } 3 \text { Pariaman direalisasikan dalam tiga tahapan yaitu } \\
\text { saat pembelajaran di kelas, lingkungan sekolah, dan } \\
\text { pengawasan di luar sekolah. }\end{array}$} \\
\hline Article history: & \\
\hline Received, 05 August 2021 & \\
\hline Revised, 24 August 2021 & \\
\hline $\begin{array}{l}\text { Accepted, } 30 \text { November } \\
2021\end{array}$ & \\
\hline $\begin{array}{l}\text { Keywords: } \\
\text { Implementasi, Nilai-Nilai }\end{array}$ & \\
\hline Religiusitas, Pembelajaran & \\
\hline PAI & \\
\hline Clonflict of Interest: & \\
\hline None & \\
\hline Funding: & \\
\hline None & \\
\hline
\end{tabular}

Corresponding Author: Desi Purnama Sari, Department Islamic Education, Faculty of Social Science, Universitas Negeri Padang, Indonesia, Email: desipurnama512@gmail.com Phone: +6281363411887

\section{Pendahuluan}

Semakin berkembangnya ilmu pengetahuan dan teknologi membuat peserta didik lebih mudah dalam mengakses berita maupun informasi. Sebagai contohnya baik media massa maupun meda elektronik, informasi tentang peristiwa-peristiwa, pesan, pendapat, berita, ilmu pengetahuan lain dan sebagainya sangat mudah diterima. Hal tersebut menjadikan media massa maupun media elektronik seperti smartphone mempunyai peranan penting dalam proses transformasi nilai-nilai dan norma-norma baru terhadap peserta didik. Mereka cenderung mencoba atau meniru apa yang dilihatnya. Disinilah impementasi pembelajran PAI sangat dibutuhkan dalam proses menanamkan nilai agama atau nilai-nilai religiusitas, agar nilai-nilai yang ada pada diri peserta didik tidak hilang namun semakin meningkat seiring perkembangan zaman. 
Desi Purnama Sari dan Murniyetti: Implementasi Pembelajaran Pendidikan Agama Islam...

Menurut Zakiah Daradjat (2014) sebagai seorang pengajar sekaligus pendidik bagi muridmuridnya, guru merupakan faktor penentu dalam keberhasilan setiap usaha pendidikan. Oleh sebab itu setiap inovasi di dunia pendidikan, khususnya sumber daya manusia dan kurikulum yang dihasilkan selalu bermuara pada faktor guru. Guru Pendidikan Agama Islam harus memiliki kompetensi untuk dapat menanamkan nilai-nilai religiusitas pada peserta didik dalam pembelajaran yang disesuaikan dengan tema atau materi pelajaran yang disampaikan serta dukungan lembaga pendidikan juga dibutuhkan untuk mewujudkan hal tersebut.

Pengaruh dalam menanamkan nilai-nilai religiusitas dan perilaku keberagamaan pada lembaga pendidikan, khususnya pada lembaga pendidikan formal (sekolah) banyak tergantung dari bagaimana karakteristik pendidikan agama yang diberikan di sekolah tersebut. Hal tersebut dikarenakan sekolah dalam perspektif Islam, berfungsi sebagai media realisasi pendidikan berdasarkan tujuan pemikiran, aqidah dan syariah dalam upaya penghambaan diri terhadap Allah dan mentauhidkan-Nya sehingga manusia terhindar dari penyimpangan fitrahnya (Ondeng, 2004).

Implemetasi Pendidikan Agama Islam dan lingkungan di sekolah hendaknya dapat menanamkan niali-nilai religiusitas serta membentuk kepribadian peserta didik menjadi manusia yang beriman dan bertaqwa. Religiusitas adalah penghayatan seseorang terhadap segala sesuatu yang ia lakukan semata-mata hanya untuk Allah SWT sehingga mendorongnya untuk bertingkah laku, bersikap dan bertindak sesuai dengan ajaran agama yang dianutnya (Jalaludin, 2002). Menurut Glock dan Stark (dalam Mustari, 2014) religiusitas memiliki lima dimensi: (1) Dimensi keyakinan agama, (2) Dimensi peribadatan/praktek agama, (3) Dimensi pengetahuan agama, (4) Dimensi pengalaman agama, (5) Dimensi Konsekuensi. Kelima dimensi tersebut saling berkaitan dan berkesinambungan satu sama lain. Dalam penelitian ini penulis lebih memfokuskan kepada dimensi peribadahan atau praktek agama, karena ibadah adalah bukti ketaatan seorang hamba kepada Tuhannya.

Ibadah juga dapat diperhatikan dari luar diri seseorang, seperti saat melakukan shalat, membaca Alquran, dan aktivitas yang berkaitan dengan praktek ibadah lainnya. Dalam menanamkan nilai-nilai religiusitas terdapat nilai-nilai religiusitas yang menjadi tolak ukur dalam pencapaian religiusitas. Terkait dengan dimensi peribadahan, nilai-nilai religiusitas yang ingin peneliti fokuskan berdasarkan pendapat Fathurrohman (2015: 60) yaitu nilai ibadah, nilai kedisiplinan, dan nilai akhlak.

Berdasarkan hasil wawacara dengan Bapak Masriko, S.PdI. selaku guru PAI di SMA Negeri 3 Pariaman, beliau menagatakan bahwa walaupun SMA Negeri 3 Pariaman berlatar belakang sekolah umum yang mana pembelajaran PAI lebih sdikit jika dibandingkan dengan madrasah aliyah dan pondok pesantren namun SMA Negeri 3 Pariaman telah mengupayakan dengan baik agar nilai-nilai religiusitas dapat ditanamkan dengan baik kepada peserta didik. Hal ini terlihat dalam visi yang dimiliki sekolah yaitu terwujudnya suasana islami bagi seluruh warga sekolah, kemudian dijabarkan dalam misi sekolah yaitu meningkatkan penghayatan dan pengamalan ajaran agama Islam. Visi dan misi tersebut bertujuan untuk menjadikan peserta didik yang lekat akan ajaran Islam dan mengamalkannya dalam kehidupan sehari-hari.

Pembiasaan-pembiasaan yang dilakukan di sekolah ini terkait dengan nilai-nilai religiusitas yang terkandung dalam ajaran agama Islam itu sendiri yaitu salah satunya mengoptimalkannya peningkatan mutu pendidikan peserta didik dan perkembangan kepribadian peserta didik baik dalam cara berfikir, bersikap, maupun cara berprilaku. Dan juga dilengkapi dengan tata tertib yang dibuat untuk seluruh warga sekolah dengan sangsisangsi bagi pelanggarnya guna meningkatkan kedisiplinan. Berdasarkan wawancara tersebut penulis tertarik untuk meneliti lebih lanjut bagaimana proses implementasi pembelajaran PAI dalam menanamkan nilai-nilai religiusitas pada peserta didik di SMA Negeri 3 Pariaman.

\section{Tinjauan Pustaka}

Pendidikan Agama Islam adalah suatu usaha yang dilakukan pendidik untuk membentuk karakter peserta didik agar sesuai dengan Alquran dan Hadist (Mahmud dkk, 2015). 
Pendidikan Agama Islam adalah mendidik manusia dalam kehidupannya untuk menjadi insan yang beriman dan bertaqwa sehingga terciptanya situasi dan kondisi masyarakat yang sejahtera dan rahmatan lil'alamin (Anwar, 2016).

Nilai merupakan sebuah kualitas dari sesuatu hal yang dapat menunjukkan bahwa hal itu disukai atau tidaknya. Nilai juga mengandung artian sesuatu yang dijunjung tinggi, mewarnai dan menjiwai tindakan seseorang. Jadi nilai adalah sebuah landasan atau dasar untuk seseorang dalam bertindak atau memilih sesuatu yang sesuai dan bermakna baik bagi kehidupannya (Fathurrohman, 2015).

Kata religi berasal dari bahasa latin religio yang akar katanya adalah religare yang berarti mengikat. Maksud religi atau agama pada umumnya, terdapat aturan-aturan dan kewajiban yang harus dilaksanakan yang semua itu berfungsi untuk mengikat dan mengutuhkan diri seseorang atau sekelompok orang dalam hubunganya dengan tuhan, sesama manusia dan alam sekitar. Religi adalah kepercayaan, sedangkan religiusitas berhubungan erat dengan sifat dan cara pandang kepercayaan seseorang terhadap tuhan (Jalaludin, 2002). Menurut Djamaluddin Ancok (dalam Aslamiyah dan Fitriah, 2018) religiusitas adalah suatu kesatuan unsur-unsur yang komprehensif yang menjadikan seseorang disebut sebagai orang yang beragama dan bukan hanya sekedar mengaku memiliki agama.

Religiusitas menurut Mustari (2014) adalah nilai karakter dalam hubungannya dengan tuhan. Ia menunjukkan bahwa pikiran, perkataan, dan tindakan seseorang yang diupayakan selalu berdasarkan pada nilai-nilai ketuhanan dan ajaran agama. Menurut Suryadi dan Hayat (2021) religiusitas dalam Islam pada garis besarnya tercermin dalam pengamalan akidah, syariah, dan akhlaq atau dengan ungkapan lain: Iman, Islam, dan Ihsan. Bila semua unsur itu telah dimiliki oleh seseorang maka seseorang dapat dikatakan insan beragama yang sesungguhnya.

Menurut Stark dan Glock (dalam Mustari, 2014) terdapat lima dimensi religius: (1) dimensi keyakinan agama, (2) dimensi peribadahan, (3) dimensi pengetahuan agama, (4) dimeni pengalaman danpenghayatan agama, (5) dimensi pengalaman dan konekuesi. Relgiusitas yng diwujudkan dalam kehidupan tidak terlepas dari satu kesatuan dimensi yang saling berkesinmbungan.

Penanaman nilai-nilai religiusitas di sekolah diharapkan dapat membentuk peserta didik yang religius. Raharjo dalam bukunya yang dikutip oleh Aslamiya dan Fitiriyah (2018:208) mengemukakan tentang ciri-ciri orang yang religius atau memiliki kematangan agama diantaranya yaitu keimanan yang utuh, pelaksanaan ibadah yang tekun dan akhlak mulia

\section{Metode}

Jenis Penelitian yang penulis gunakan adalah field research atau penelitian kualitatif yang bersifat deskriptif (Sugiyono, 2012). Metode penelitian yang digunakan yaitu metode observasi, metode wawancara dan metode dokumentasi. Adapun yang menjadi informan dalam penelitian diantaranya: a) kepala sekolah SMA Negeri 3 Pariaman, b) guru pendidikan agama Islam, c) peserta didik, d) dan orang tua dari peserta didik. Teknik analisis data dalam penelitian ini menggunakan deduktif, keterangan-keterangan yang bersifat umum menjadi pengertian khusus yang terperinci, baik dari pengetahuan yang diperoleh dari lapangan maupun kepustakaan. Teknik pengabsahan data menggunakan triagulasi sumber data (Jaya, 2020).

\section{Hasil dan Pembahasan}

Data yang disajikan disini merupakan hasil penelitian di lapangan teknik-teknik pengumpulan data yang telah ditetapkan yaitu melalui wawancara, observasi dan dokumentasi.

Menurut Fathurrohman (2015) terkait dimensi peribadahan, nilai-nilai religiusitas yang peneliti fokuskan adalah nilai ibadah, nilai kedisiplinan, dan nilai akhlak. Kata ibadah berasal dari bahasa Arab yaitu masdar 'abada yang berarti ibadah. Secara terminologi ibadah adalah usaha untuk mematuhi hukum dan aturan Allah dalam menjalankan kehidupan sesuai 
Desi Purnama Sari dan Murniyetti: Implementasi Pembelajaran Pendidikan Agama Islam...

dengan perintah-Nya. Menurut Imam Besar Ibnu Taimiyah, yakni "Ibadah adalah istilah yang meliputi segala sesuatu yang diridhoi Allah SWT dan diridhai-Nya, baik berupa perkataan dan perbuatan, yang tampak ataupun yang tak tampak (Subagyo dkk, 2010: 18).

Program pendukung dalam menanamkan nilai ibadah di SMA Negeri 3 Pariaman yaitu: (1) shalat berjamaah, (2) shalat dhuha, (3) membaca Alquran, (4) mengikuti kajian. Disiplin merupakan bagian dari proses pendidikan dan pengajaran yang berkelanjutan. Jika ada kedisipinan, semua aturan dan kegiatan dapat berjalan dengan normal. Nilai kedisiplinan perlu ditanamkan di sekolah agar dapat membuat peserta didik patuh dan tunduk kepada aturan sekolah. Kedisiplinan yang tinggi tidak hanya dapat menunjang kelancaran seluruh kegiatan sekolah, tetapi peserta didik juga dapat berlatih membiasakan diri dengan perilaku positif yang bermanfaat bagi diri sendiri dan lingkungan (Subagyo dkk, 2010: 18). Program pendukung dalam menanamkan nilai kedisiplinan di SMA Negeri 3 Pariaman yaitu: (1) shalat tepat waktu, (2) berpakaian muslim dan muslimah, (3) mematuhi aturan sekolah terkait dengan program keagamaan.

Menurut Syaepul Manan (2017: 50) akhlak adalah sifat, tabiat, atau perilaku yang dapat dengan mudah dimunculkan tanpa pemikiran lebih dulu. Jadi akhlak adalah spontanitas dari diri seseorang yang mengatur bagaimana seseorang bertindak. Nilai akhlak perlu ditanamkan di sekolah agar dapat membuat peserta didik senantiasa berperilaku baik dengan sesamanya. Program pendukung dalam menanamkan nilai akhlak di SMA Negeri 3 Pariaman yaitu menghormati guru, dan menghormati sesama warga sekolah, baik dengan yang lebih muda, sesama, dan dengan yang lebih tua.

Proses implementasi pembelajaran PAI dalam menanamkan nilia-nilai religiusitas di SMA Negeri 3 Pariaman:

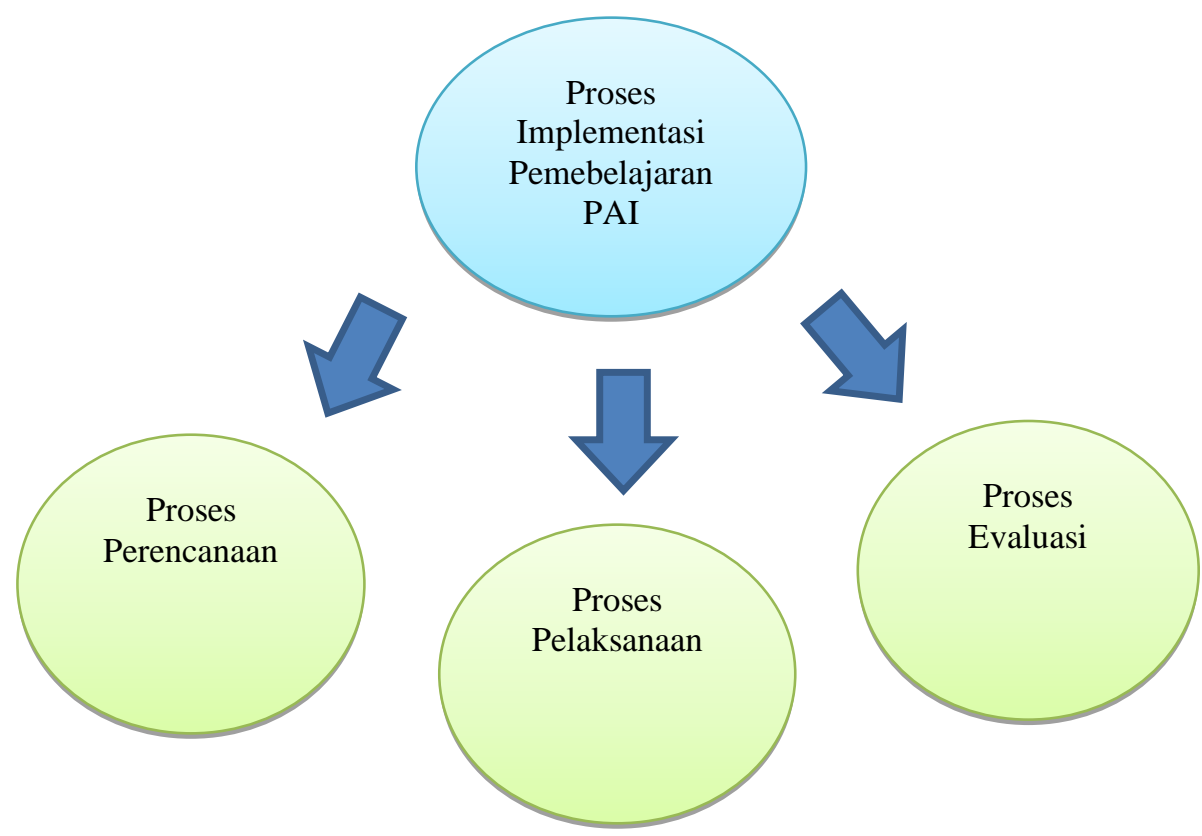

Proses perencanaan dari implementasi pembelajaran PAI di SMA Negeri 3 Pariaman yaitu guru PAI diberikan kebebasan oleh kepala sekolah dan sekolah dalam mengembangkan program-program yang ada di sekolah guna untuk mendukung implementasi pembelajaran PAI dalam menanamkan nilai-nilai religiusitas kepada peserta didik, karena yang lebih mengetahui dibidang agama adalah guru PAI itu sendiri.

Proses pelaksanaan dari implementasi pembelajaran PAI di SMA Negeri 3 Pariaman direalisasikan saat pembelajaran di kelas, lingkungan sekolah dan pengawasan di luar sekolah.

Tabel 1. Tahapan Pelaksanaan 


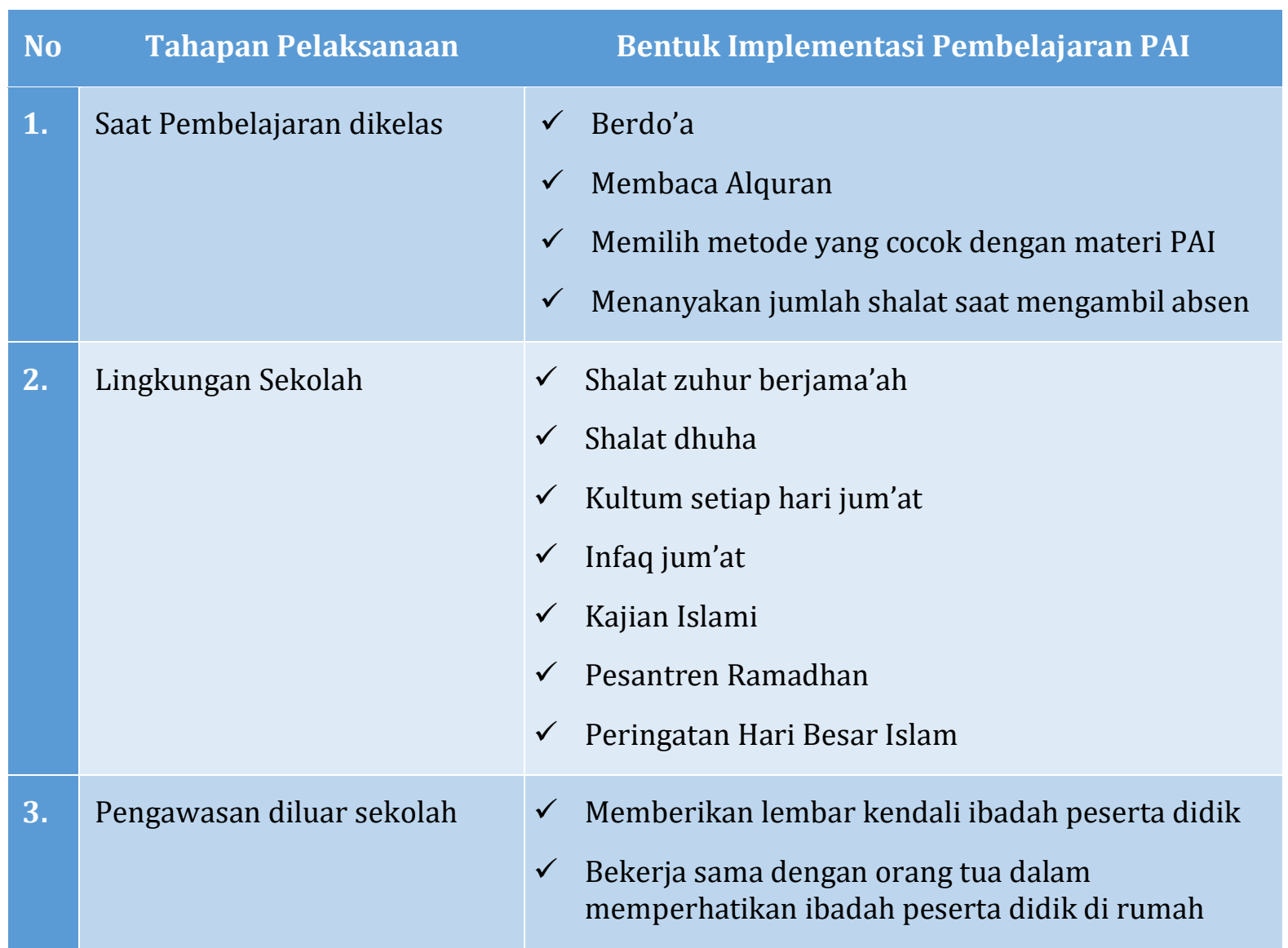

Metode yang digunakan dalam proses pelaksanaan implementasi pembelajaran PAI di SMA Negeri 3 Pariaman yaitu metode pembiasaan, metode keteladanan, metode kedisiplinan, metode hukuman, dan metode motivasi. Sehubungan dengan hal tersebut, menurut Ahmad Tafsir yang dikutip oleh Manan (2017) menyebutkan ada beberapa bentuk upaya yang dapat dilakukan guru dalam menanamkan nilai-nilai religiusitas di sekolah, antara lain: memberikan contoh atau teladan, membiasakan, menegakkan disiplin, memberikan motivasi atau dorongan, memberikan hadiah, memberikan hukuman dan menciptakan suasana yang religius.

Proses evaluasi yang dilakukan guru PAI yaitu dengan melihat perubahan pada diri peserta didik seperti dari bacaan Alqurannya, kehadiran shalat berjama'ah, sikap dan perilaku peserta didik sehari-hari.

Implementasi pembelajaran PAI dalam menanamkan nilai-nilai religiusitas membawa perubahahan yang positif kepada peserta didik. Peserta didik jadi lebih rajin beribadah dan mudah diatur serta sudah menerapkan sikap sopan santun dalam kehidupan sehari-hari. Program-program yang ada memberikan dampak positif kepada peserta didik, mereka yang awalnya tidak terlalu memperhatikan kegiatan ibadahnya, dengan adanya program tersebut ibadahnya menjadi lebih rajin dan tepat waktu.

Raharjo dalam bukunya yang dikutip oleh Aslamiya dan Fitiriyah (2018:208) mengemukakan tentang ciri-ciri orang yang religius atau memiliki kematangan agama diantaranya yaitu keimanan yang utuh, pelaksanaan ibadah yang tekun dan akhlak mulia. Menurut guru PAI peserta didik yang berkarakter religius adalah peserta didik yang menghormati guru dan menghormati orang tuanya. Dia tahu bagaimana cara bersikap dengan orang yang lebih tua, sebaya, dan yang lebih muda. Guru PAI lebih mengutamakan akhlak mereka daripada yang lainnya. Barulah yang shalatnya rajin dan yang sering berjama'ah di masjid.

Faktor pendukung implementasi pembelajaran PAI dalam menanamkan nilai-nilai religiusitas di SMA Negeri 3 Pariaman adalah adanya dukungan dari guru PAI dan guru 
Desi Purnama Sari dan Murniyetti: Implementasi Pembelajaran Pendidikan Agama Islam...

lainnya, guru memberikan contoh teladan yang baik kepada peserta didik. Guru ikut serta dalam kegiatan-kegiatan yang dilakukan oleh peserta didik. Adanya dukungan dari peserta didik sendiri seperti mereka tidak terbebani dengan adanya program-program yang mendukung implementasi pembelajaran PAI dalam menanamkan nilai-nilai religiusitas. Adanya sarana dan prasarana yang mendukung seperti musala sekolah, tempat wudhu yang memadai dan perlengkapan shalat. Adanya dukungan dari kepala sekolah seperti memberikan kebebasan kepada guru PAI dan berinovasi mengembangkan program-program yang mendukung implementasi pembelajaran PAI. Terakhir yaitu adanya dukungan dari orang tua peserta didik, guru PAI bekerjasama dengan orang tua untuk senantiasa memperhatikan ibadah dan tata cara berpakaian peserta didik di rumah.

Faktor penghambat implementasi pembelajaran PAI dalam menanamkan nilai-nilai religiusitas di SMA Negeri 3 Pariaman yaitu tempat ibadah yang tidak bisa menampung banyaknya peserta didik, adanya peserta didik yang malas akibat pengaruh teman sebaya dan lingkungan serta alokasi waktu pembelajaran PAI yang terlalu sedikit dalam seminggu. Upaya yang dilakukan guru PAI dalam mengatasi faktor penghambat yaitu peserta didik boleh shalat berjama'ah di kelas dan di masjid terdekat, memberikan hukuman bagi peserta didik yang tidak melaksanakan kegiatan dan menambah jam pembelajaran PAI diluar jam pembelajaran yang ada.

\section{Simpulan}

Berdasarkan hasil penelitian dari uraian di atas, peneliti menarik kesimpulan sebagai berikut: Pertama, implementasi pembelajaran PAI di SMA Negeri 3 Pariaman direalisasikan dalam tiga tahapan yaitu: saat pembelajaran di kelas, lingkungan sekolah dan pengawasan diluar sekolah. Kedua, faktor pendukung dari implementasi pembelajaran PAI dalam menanamkan nilai-nilai religiusitas yaitu adanya dukungan dari guru, dukungan dari peserta didik, dukungan dari kepala sekolah, dukungan dari sarana dan prasarana dan dukungan dari orang tua peserta didik. Faktor penghambatnya yaitu tempat ibadah yang tidak bisa menampung banyaknya peserta didik, adanya peserta didik yang malas akibat pengaruh teman sebaya dan lingkungan serta alokasi waktu pembelajaran PAI yang terlalu sedikit dalam seminggu. Upaya yang dilakukan guru PAI dalam mengatasi faktor penghambat yaitu peserta didik boleh shalat berjama'ah di kelas dan di masjid terdekat, memberikan hukuman bagi peserta didik yang tidak melaksanakan kegiatan dan menambah jam pembelajaran PAI diluar jam pembelajaran yang ada.

\section{Referensi}

Anwar, S. (2016). Peran Pendidikan Agama Islam dalam Membentuk Karakter Bangsa. Jurnal Pendidikan Islam, 7.

Aslamiyah, S. S., \& Fitriyah, A. (2018). Upaya Guru PAI Dalam Meningkatkan Religiusitas Peserta Didik. Akademika, 12(02).

Fathurrohman, Muhammad. (2015). Budaya Religius dalam Meningkatkan Mutu Pendidikan, Yogyakarta: Kalimedia.

Jalaludin. (2002). Psikologi Agama. Yogyakarta: Raja Grafindo Persada.

Jaya, I. M. L. M. (2020). Metode Penelitian Kualitatif dan Kuantitatif (F. Husaini (ed); pertama) QUADRANT.

Mahmud dkk. (2015). Pendidikan Agama Islam Berbasis Multietnik. Jakarta: Deepublish.

Manan, S. (2017). Pembinaan Akhlak Mulia Melalui Keteladanan dan Pembiasaan. Jurnal Pendidikan Agama Islam-Ta'lim, 15(1), 49-65.

Mustari. (2014). Nilai Karakter Refleksi Untuk Pendidikan. Yogyakarta: Raja Grafindo Persada.

Ondeng, syarifuddin. (2004). Islam dalam Berbagai Dimensi; Kajian tentang Agama, Sejarah dan Pendidikan. Cet. I; Makassar: Berkah Utami.

Subagyo dkk. (2010). Religiusitas, agama, dan budaya nilai. Jakarta: Grasindo. 
Sugiyono. (2012). Metode Penelitian Pendidikan Pendekatan Kuantitatif, Pendekatan Kualitatif, Kualitatif dan R\&D. Bandung: Alfabeta.

Suryadi, bambang \& Bahrul Hayat. (2021). Religiusitas Konsep, Pengukuran, dan Implementasi di Indonesia. Jakarta: Bibliosmia Karya Indonesia.

Zakiah Daradjat, (2014). Ilmu Jiwa Agama. Jakarta: Bumi Aksara. 